\title{
Why 'state of the art' monetary theory was unable to anticipate the global financial crisis: a child's guide
}

\author{
Colin Rogers \\ School of Economics, University of Adelaide, Australia
}

'State of the art' monetary theory was unable to anticipate or understand the global financial crisis because it rested on microeconomic foundations that precluded any meaningful role for money, finance or banking. These analytical and conceptual flaws have been known for a long time. But many either ignored or misunderstood their implications. This note provides a largely non-technical explanation of the conceptual flaws in 'state of the art' monetary theory that rendered it unable to anticipate, or understand, the global financial crisis of 2007-2008; and rendered it thereafter effectively useless as a guide to what should be done.

Keywords: time-0 auction, money-less Walrasian-Arrow-Debreu models

JEL codes: $E 40, E 42, E 50, D 53$

\section{INTRODUCTION}

The global financial crisis (GFC) of 2007-2008 prompted many to question the state of contemporary macroeconomics and monetary theory. Buiter (2009), Krugman (2009), Rodrik (2009) and White (2009) are leading examples. The Economist (18-24 July 2009) also presented a leader and two briefings outlining criticisms of the state of academic macroeconomics, money and finance theory, to which Lucas (2009) responded with a defence of what he called this 'dismal science'. ${ }^{1}$

Perhaps the most persistent of critics was Buiter (1998; 2002; 2004; 2007; 2008; 2009), particularly his blog entitled: "The unfortunate uselessness of most "state of the art" academic monetary economics' (re-posted as Buiter 2009), which was particularly strident in pointing out that most contemporary monetary theory was incapable of understanding let alone providing advice about how to respond to the global crisis. ${ }^{2}$ In particular, Buiter stated that:

Both the New Classical and New Keynesian complete markets macroeconomics theories not only did not allow questions about insolvency and illiquidity to be answered. They did not allow such questions to be asked. (Buiter 2009: 6 March)

1. As Frankel (2009) notes, Lucas's observation that the current criticisms have been made before is hardly a defence of 'state of the art' monetary theory.

2. Clower (1999) had earlier launched a similar strident but prescient broadside at the state of monetary and finance theory.

Received 5 June 2013, accepted 14 January 2014 
In fact the flaws in contemporary monetary theory to which Buiter refers have been well known since at least Hahn (1965), but Hahn's (1982) warning that their implications have not been fully understood remains true.

These flaws are conceptual, are hard-wired into all new schools of monetary economics ${ }^{3}$ (new classical (NC) or real business cycle (RBC) and new Keynesian (NK) monetary theory) and are largely inherited from older conceptual mistakes embedded in the Walrasian general equilibrium theory employed by Patinkin; Hahn's (1965) initial critique was directed at Patinkin (1955 [1965]). Post the GFC, these conceptual mistakes have not been addressed, so contemporary monetary theory remains a poor a guide to current events.

To illustrate these properties and explain why 'state of the art' monetary theory was incapable of anticipating or explaining the GFC in particular or financial crises and monetary policy in general, this paper provides a largely non-technical explanation of the conceptual flaws in NC and NK monetary economics.

Section 2 outlines the fundamental nature of the conceptual problem hard-wired into contemporary monetary theory using Wallace's (2004) attempt to find a role for the central bank in a cashless (read money-less) Arrow-Debreu economy. The inability of this form of theorising to understand the concept of liquidity is then illustrated using Allen/Gale's (2007) notion of liquidity as an example of Buiter's (2009) criticism.

Section 3 then explains how the conceptual problems revealed in Section 2 are also embedded in the core of NC and NK monetary theory. McCandless (2008) provides a candid exposé of the inadequate treatment of money in some RBC models, while an examination of Galî's (2008) introduction to NK monetary theory reveals the same conceptual problems.

Section 4 briefly examines why so many theorists continue to use these models despite acknowledging the ad hoc properties of their theory. Section 5 summarises and concludes.

\section{THE CONCEPTUAL CONFUSIONS THAT ARISE FROM THE USE OF THE WALRASIAN-ARROW-DEBREU CORE AS THE FOUNDATION FOR MONETARY THEORY}

The conceptual confusion to which Buiter and others point arises as a result of the implicit belief that Walrasian general equilibrium theory, of which the Arrow-Debreu model is the most 'advanced' form (hereafter described as the Walrasian-Arrow-Debreu (WAD) core), is the scientific standard to which monetary theory must aspire. Put simply, the fatal flaw for monetary theory embedded in the WAD general equilibrium core arises from the necessary assumption of a time- 0 auction. This auction allows recontracting so that only equilibrium trades are determined at time zero $(t=0)$ but apply across all future dates as agents optimise over an infinite time horizon.

The technical necessity for this assumption is often overlooked because it is conflated with the notion of perfect competition, price flexibility and market clearing (see, for example, Gali 2008: 15). But the latter is not equivalent to the former and the former is a necessary element of any WAD core general equilibrium model. Thus, in addition to the traditional three elements treated as axiomatic - tastes, endowment and technology - all WAD general

3. The new monetarism of Williamson/Wright (2010) was not an element of 'state of the art' monetary theory before the GFC, so will not be considered here even though it has similar conceptual problems caused by the addition of a search theory component, where money has a role, to a component with a centralised auction where money has no role. The non-Ricardian analysis of Benassy (2007) is also open to the critique outlined in this paper but it was not part of 'state of the art' monetary theory prior to the GFC. 
equilibrium models must include the time- 0 auction as the fourth axiom. Without such an auction, or something analytically equivalent to it, all forms of the WAD equilibrium core collapse into indeterminacy and intractability. The need for this necessary assumption is seldom addressed, because the WAD core is also conflated with the notion that it provides the 'sound' microeconomic foundations necessary for all macroeconomic and monetary theory. ${ }^{4}$

Consequently, all contemporary or 'new' monetary models contain a WAD general equilibrium core onto which are appended various ad hoc structures that are intended to represent some element of reality, particularly money, that is not captured by the WAD core. To illustrate these issues, it is useful to begin with Wallace (2004), because, although Wallace (2001) is aware of the puzzles and inconsistencies in much of 'state of the art' monetary theory, his attempt to find a role for a central bank in the Arrow-Debreu model suggests a lack of appreciation for the cause of what he calls the 'hidden' inconsistencies in that theory. ${ }^{5}$ Nevertheless, Wallace (2004) also provides a definitive statement of the view that the Arrow-Debreu model is the appropriate theoretical foundation for monetary theory. This is the fundamental conceptual mistake that undermines NC and NK monetary theory.

\subsection{Wallace on 'Central-bank interest-rate control in a cashless, Arrow-Debreu economy'}

The most startling feature of Wallace's (2004) analysis from the perspective of a WAD general equilibrium theorist is that it stands in direct contradiction to Hahn (1965; 1973a; 1973b; 1982). In other words, it attempts the impossible.

As noted above, it is a well-established fact that the Arrow-Debreu model has no role for money. It should therefore be self-evident that the Arrow-Debreu model also has no use for the price level or any role for a central bank. As Hahn (1965; 1973a; 1973b) explained long ago, there is no essential role for money or a central bank in the Arrow-Debreu model. Hahn (1982: 1, emphasis added) could not have been more specific:

The most serious challenge that the existence of money poses to the theorist is this: the best developed model of the economy cannot find room for it. The best-developed model is, of course, the Arrow-Debreu version of a Walrasian general equilibrium. A world in which all conceivable contingent future contracts are possible neither needs nor wants intrinsically worthless money. The point is obvious and has been made quite often. But it is doubtful that it has been fully taken on board.

What Hahn is telling us here is that there is no role for money in a world where all contingent futures contracts are hard-wired into the microeconomic foundations of the model. But what sort of a world is this? As Ljungqvist/Sargent (2004: 217, emphasis added) explain, it is a world that rests on a time- 0 auction:

In the competitive equilibrium, all trades occur at $t=0$ in one market. Deliveries occur later than $\mathrm{t}=0$, but no more trades. A vast clearing or credit system operates at $t=0$. It ensures that condition (8.5.1) [the household's budget constraint] holds for each household $i$. A symptom of the once-andfor-all trading arrangement is that each household faces one budget constraint that accounts for all trades across dates and histories.

4. Solow (1986) warned that equating microeconomic foundations with Walrasian general equilibrium theory was a mistake.

5. Wallace (2001: 847) points out that models with money in the utility or production functions or with cash-in-advance constraints have hidden inconsistencies. He also explicitly notes, correctly, that in these models there may be no asset markets and therefore no way in which central banks can conduct open market operations. 
All WAD general equilibrium theories rest on an auction of this type and although there are variants of this time- 0 auction, such as sequential trading with Arrow-securities, these formulations are specified in such a way that they are analytically equivalent to the time-0 auction, as Ljungqvist/Sargent (2004: ch8) explain. Consequently, a model based on a time-0 auction or its analytical equivalent has no role for money - there is no money in Debreu (1959) because none is required. For the same reason, there should be no money in Patinkin (1955 [1965]), Woodford (2003) or Wallace (2004).

Hence it should come as no surprise that Wallace is unable to prove the existence of a 'competitive' monetary equilibrium when he attempts to introduce a monopolist price-setter (the central bank) and money into a model with an auctioneer and the time- 0 auction.

The deep conceptual flaw in Wallace's (2004) analysis is stated explicitly. After lauding the Arrow-Debreu model as the developed part of economic theory, and monetary theory as the underdeveloped part, he goes on to say:

$\ldots$ as it happens, the Arrow-Debreu model has room for a unit of account - what is called an abstract unit of account, abstract in the sense of not having a physical counterpart. This note describes conditions under which an activity that resembles central bank open market operations determines nominal interest rates in a simple Arrow-Debreu model. (Ibid.: 1, emphasis added)

What more can we say about this description?

First, this statement is an illustration of the gross misapplication of the Arrow-Debreu model. There is no need for either money or nominal values in the model because the auctioneer conducting the time- 0 auction provides all the real relative exchange ratios (actually quantities - how much jam it takes to acquire a Porsche in 2056!). All the real-world frictions of barter that money overcomes are non-existent in the Arrow-Debreu model. In fact, the model has nothing to say about how the equilibrium trades it generates are actually executed. So, in a sense, the WAD core is better described as a world of perfect barter. In contemporary jargon it contains no transactions technology.

Even if we can digest that obstacle, the explanation provided by Wallace raises a range of additional questions. First, what is a central bank doing in a model based on the time- 0 auction? In particular, how does the central bank relate to the auctioneer? Recall that, in the Arrow-Debreu model, dated real relative prices (actually time and space are analytically equivalent in the model) are generated by the time- 0 auction and can be expressed as commodity interest rates; so there are as many interest rates as there are commodities. All of these interest rates are determined simultaneously with relative prices and satisfy the no-arbitrage condition under the time- 0 auction. So, which of these commodity interest rates is the central bank supposed to manipulate by overruling the auctioneer? Is the central bank to monopolise the supply of jam, for example, and thereby 'set' the jam rate of interest? Or is the interest rate perhaps expressed in terms of the commodity selected as the numeraire? But, as Wallace also tells us that the numeraire need have no physical existence, how is the central bank to conduct open market or repurchase operations to control that interest rate? ${ }^{6}$ There are no sensible answers to these questions.

Furthermore, the fact that a numeraire can be used in Wallace's Arrow-Debreu model neither converts the numeraire into money nor introduces the use of nominal values. In particular, for money to exist, in addition to its numeraire function, it must also act as a means of final settlement, as Hoover (1988) explained. No such function is needed or defined in the Arrow-Debreu model. Consequently there are no nominal values in the model - it is illegitimate to treat the numeraire and nominal values as synonyms in

6. Woodford (2003) has the same question to answer when his model is in the cashless limit; see Rogers $(2006 ; 2011)$ and the discussion below. 
that context. As McCallum (1985; 2004) explained, it is possible to interpret a model based on a time- 0 auction as an accounting system of exchange, but that interpretation does not mean it is a monetary model, because, in particular, the medium of exchange (or final settlement function of money) is not required.

Thus Wallace's (2004) attempt to introduce a central bank into an Arrow-Debreu model inevitably collapses and reveals some of the 'hidden' inconsistencies he mentions in Wallace (2001). Essentially what Wallace (2004) does is rediscover Hahn's (1965) conclusion: it is not possible to prove the existence of a monetary equilibrium in a model in which money is an inessential addition - that is to say, in a model based on a time- 0 auction.

\subsection{Allen/Gale on 'Understanding financial crises' in an Arrow-Debreu world}

The conceptual difficulties outlined above are almost the leitmotif of 'state of the art' monetary theory. That theory also draws its inspiration from finance theory (attracted by the no-arbitrage condition?) and Buiter (2009) takes particular aim at the inability of that theory to grasp the concepts of liquidity and insolvency.

From what we have seen so far, the concept of liquidity is always going to pose a challenge for a moneyless model if liquidity is defined as the ability to convert an asset into money at short notice with minimum loss. Consequently, the common definition of liquidity is abandoned by Allen/Gale (2007), who provide the following definition of a short-term liquid asset as:

a storage technology that allows one unit of the good at date $t$ to be converted into one unit of the good at date $t+1$, for $t=0$, 1. (Ibid.: 53 , emphasis added)

A WAD-trained general equilibrium theorist will immediately recognise this sleight of hand. An examination of this definition of liquidity reveals that the 'storage technology' to which Allen/Gale are referring here is nothing more than the time- 0 auction that permits the trade of one unit of jam today (date $t$ ) for one unit of jam at any future date (date $t+j$; $j=1,2,3, \ldots)$. In this case, if jam is the numeraire, the dated relative price is unity, and because dated relative prices can be quoted as interest rates, in this case the jam rate of interest is zero. But, as noted previously, this does not convert jam into money or a liquid asset, as those terms are generally understood. Of course, as Buiter has repeatedly explained, instead of the jam rate of interest, it could be the non-existent phlogiston rate of interest or any other commodity rate expressed in terms of any arbitrarily selected commodity as numeraire.

The point here is that the concept of liquidity defined by Allen/Gale and many other 'finance' theorists is not the concept of liquidity necessary to understand money and financial markets and how they might behave in a financial crisis. Surely the GFC taught us one thing: without the ability to convert assets into money, financial markets simply freeze! But the time- 0 auction avoids that problem, as all commodities are always (at all dates and states of nature) equally 'liquid'. Trades (markets?) cannot 'freeze' under a time-0 auction. Thus, as Buiter (2009) stresses, academics armed with models of the Allen and Gale type would not have been in a position to ask the right questions about liquidity or insolvency in the GFC of 2007-2008, let alone answer them.

\section{HOW THE CONCEPTUAL CONFUSION ABOUT MONEY IN THE WAD CORE IS TRANSFERRED TO CONTEMPORARY MONETARY THEORY}

Although a discussion of the role of money in RBC models looks like an oxymoron, it is useful to consider it first, as it reveals the perennial problem faced by attempts to find a role for 
money in any model based on the WAD general equilibrium core. It also provides a clear statement of the problem faced by NK monetary theory as the RBC theory forms the foundation for that monetary theory. The NK model simply collapses to the RBC model when there is full wage and price flexibility. In that respect, it is difficult to see why NK monetary theory is any different from NC monetary theory.

\subsection{Money in RBC models}

The role of money in RBC models is summarised by McCandless (2008), who presents the by-now standard specification of a cash-in-advance (CIA) model, the workhorse of much 'state of the art' monetary theory, and rather candidly makes the following remark:

Adding money to the model creates an additional complication in solving the models. The presence of money puts a friction into the economy so that the equilibrium will not necessarily be that of a frictionless competitive equilibrium. The second welfare theorem allowed us to use a Robinson Crusoe (representative agent) type model to solve for a multi-agent equilibrium because, without frictions, the equilibria would be the same. Here we need to work explicitly with multiple agents, with markets, and with the friction of money. (Ibid.: 184 emphasis added)

There are several aspects in this description that require comment. The most glaring is the claim that money is a friction in RBC models. Unfortunately, this is an accurate description of the consequence of imposing money on models where it is not required. But as Clower (1984: 267) realised, that reduces the model to non-sense:

Specifically, the model implied that the choice alternatives confronting households were more restrictive in a money than a barter economy, which meant that monetary exchange is less efficient than barter exchange ...

The reason why money is converted from a lubricant to a friction is essentially this: the RBC or WAD core has no need for money - it is a redundant concept. So if agents in the model are then forced to use money by the imposition of a cash-in-advance (CIA) constraint, as a concession to naive realism, they face an additional constraint that does not exist under the time- 0 auction. In that case, monetary exchange in the WAD model, or its RBC version, appears to be less efficient than that of a barter or non-monetary economy - a friction rather than a lubricant - which, as Clower (1984: 267) notes, is contra 200 years of conventional wisdom and common sense.

Similar conceptual conundrums appeared in the money-growth literature in the late 1960s and Purvis (1971) provides an insightful summary. In particular, he notes that the introduction of money into an otherwise 'barter' model does not adequately address the differences between monetary and barter systems or incorporate the means of final settlement function of money. In these Solow-type models, real money balances are treated as an asset that competes with capital as a home for saving and so depresses the steady state per-capita capital ratio which struck many as counterintuitive. Unlike 'saving', real money balances cannot be invested in the model, yet economies with well-developed financial systems should be more efficient than barter systems at mobilising saving and directing it to productive investment; so the steady state capital per capita should, by comparison, be higher in such an economy.

More recently, Reis (2007) showed that a similar conclusion applied to a money-ingrowth model, based on what are often claimed to be sound microeconomic foundations. Reis (2007: 135) concludes:

In the model of this note [Sidrauski (1967)], the optimal policy is Friedman's $R_{t}=0$, so that holding money is costless and equilibrium replicates that of the economy without money. 
The fact that many central banks reduced short-term nominal rates of interest, $R_{t}$, to zero in the GFC without converting the economy into a non-monetary state illustrates Purvis's (1971) point.

These conundrums are, however, easily resolved once it is realised that the comparisons between barter or non-monetary and monetary versions of the models are invalid. Money is not required in these models, as all the functions it performs are already embedded in the equations of the non-monetary versions by the time- 0 auction or its equivalent. For example, Purvis (1971) suggested that the production function in a monetary economy is more efficient than that of a barter or non-monetary economy but there is no need to explicitly incorporate money. But that is cold comfort to monetary theorists who have nothing to study! Furthermore, it is an insight that escapes those who seek to insert money into these models.

\subsection{New Keynesian monetary theory - Galí's New Keynesian model}

Rogers (2013) provides a comprehensive critique of NK theory (see also Dullien 2009), so here we concentrate mainly on the monetary aspects. Put simply, NK monetary theory takes the $\mathrm{RBC}$ core and the ad hoc CIA constraint (or money demand equation) and then adds additional ad hoc elements such as imperfect competition and constraints on nominal price adjustments to cause 'unemployment' (actually a misallocation of labour as there is no involuntary unemployment in NK models). ${ }^{7}$

The strategy of appending ad hoc restrictions to a WAD general equilibrium core to produce NK models is evident from Galí (2008), where chapter 2 presents a classical monetary model (an RBC model with a money demand equation) and chapter 3 presents the NK version derived from it by imposing additional ad hoc 'nominal frictions'.

As Rogers (2013: 179-180) explains, the nominal frictions introduced by Galí to the production technology are captured by two parameters: $\theta$ that reflects the degree of price stickiness, and $\mu$ that reflects the deviation of prices from perfectly competitive prices due to imperfect competition. But both of these parameters may be set to zero, and the NK model then collapses to Galís classical monetary model. Like a series of Russian dolls, the classical monetary model then collapses to the RBC or WAD core when it is convenient to drop the money demand equation. ${ }^{8}$ In the latter state the model is said to be in the cashless (read money-less) limit.'

7. Patinkin (1955 [1965]: ch13) attempted to introduce involuntary unemployment by forcing households off their labour supply curve, but this implies irrational or non-optimising behaviour by households. That is, it is behaviour that is not consistent with the microfoundations and Walrasian auction that Patinkin was employing.

8. Here it is useful to point out that when $\mu \neq 0$ and $\theta=0$ (full wage and price flexibility with imperfect competition), Galî's model generates an inefficient allocation of resources relative to the RBC model (full wage and price flexibility under perfect competition (read a time- 0 auction)). When $\mu=0$ and $\theta \neq 0$, firms face an additional constraint that prevents them from maximising profits. In Galîs model, having introduced price setting firms as a token to realism, price setting firms are prevented from adjusting prices when faced with a shock to marginal costs. The conceptual problem faced by Patinkin (1955 [1965]: ch13), when wage stickiness was imposed on the labour market, is shifted to the goods market, when price stickiness is imposed on firms in NK models. Furthermore, like the central bank, Galí never explains how price setting firms are reconciled with the auctioneer. These are examples of the hidden inconsistencies mentioned by Wallace (2001) that arise in these models when attempts are made to introduce concepts into a model where they are not defined or where they are not required. In any event, all these inessential epicycles disappear when the NK model collapses to the RBC model.

9. There is a tendency in this literature to equate the evolution of money from cash (notes and coins) to electronic transfer (e-money) with the properties of the WAD core. But a 
In short, the NK model consists of a money-less WAD general equilibrium core to which an ad hoc money demand or quantity equation is added to produce a monetary version of that model. To produce non-neutral responses to monetary shocks, nominal frictions are then added to the supply side (firms) of the model to produce inefficient allocations. ${ }^{10}$ Galí (2008: 24) motivates the strategy as follows:

The [classical monetary] model cannot explain the observed real effects of monetary policy on real variables. Its predictions regarding the response of the price level, nominal rate, and money supply to exogenous monetary policy shocks are also in conflict with the empirical evidence. Those empirical failures are the main motivation behind the introduction of nominal frictions in otherwise similar models, a task I will undertake in chapter 3.

Here we are concerned only with the ad hoc monetary aspects of the model, to illustrate that it simply reflects the old classical approach to monetary theory rejected by Patinkin $(1955$ [1965]) but more importantly by Hahn (1965; 1982). The supply side, firms and technology, and the strange role of government, will not be explicitly considered. (For a discussion of those aspects, see Dullien 2009 and Rogers 2013.)

First, consider the money-less WAD general equilibrium core of the model. Following Galí (2008), as a representative of 'state of the art' NK monetary theory, assume an infinitely lived household that seeks to maximise:

$$
E_{0} \sum_{t=0}^{\infty} \beta^{t} U\left(C_{t}, N_{t}\right)
$$

where $C_{t}$ is a composite commodity and $N_{t}$ represents hours of leisure, subject to a sequence of flow budget constraints

$$
P_{t} C_{t}+Q_{t} B_{t} \leq B_{t-1}+W_{t} N_{t}-T_{t}
$$

for $t=1,2,3, \ldots$, and, where $P_{t}$ is said to be the price index for the composite commodity, $W_{t}$ is said to be the nominal wage, $B_{t}$ is said to be the quantity of one-period nominally riskless discount bonds purchased in period $t$ and maturing in period $t+1$. Each bond is said to pay one unit of money at maturity and its price is $Q_{t}$. The variable $T_{t}$ represents lump-sum additions or subtractions to period income in the form of dividends, taxes or transfers expressed in nominal terms.

It is also assumed that the household is subject to a solvency constraint:

$$
\lim _{T \rightarrow \infty} E\left\{B_{T}\right\} \geq 0
$$

for all $t .^{11}$

cashless economy using only e-money is a monetary economy, while the WAD core under a time- 0 auction is indeed cashless and non-monetary. There is no role for e-money in the WAD core.

10. The concepts of neutral money and inessential money are not the same and need to be distinguished. In Galí's model, if $\mu=0$ and $\theta \neq 0$, money is said to be non-neutral, because monetary shocks are said to have real effects. Removing those nominal rigidities by setting $\theta=0$ produces the neutral money outcomes of the RBC model. But money is an inessential addition to both versions of the model.

11. Goodhart $(2005 ; 2009)$ has consistently pointed out that ruling out bankruptcy - that is, Lehman events - as the transversality condition (3) does, rather defeats the purpose of applying these models to understand financial crises. 
There are a number of counterintuitive elements in this presentation that reveal the conceptual problems inherited from the WAD core or the RBC model.

First, if we ask ourselves what sort of world expression (1) describes, it is immediately apparent that it requires some special characteristics. In particular, expression (1) states that households can engage in consumption loans across time, and space, without the intervention of money or credit. In what sort of world is this possible? WAD-trained theorists have long had an answer to this question: expression (1) requires the existence of the time- 0 auction.

In other words, for the microeconomic foundations of expression (1) to be well defined, the existence of a time- 0 auction or equivalent is necessary. ${ }^{12}$ Without such an auction, expression (1) is not defined, because it is otherwise impossible for consumers to make dated trades of consumption goods without the use of money or credit. Thus the existence of a time- 0 auction is necessary to rationalise equation (1), but, as noted above, this requirement is fatal for monetary theory, because, as Laidler (1990) explained, the time- 0 auction and money are analytical substitutes not complements: a model can include one, but not both. ${ }^{13}$

Second, it is already apparent from Galî's explanation of the microeconomic properties of the model that he has committed the conceptual mistake noted above by attributing nominal magnitudes to elements of the budget constraints, expression (2). It should be apparent by now that no nominal values can be defined under the time- 0 auction, because it allows real consumption loans or trades without the intervention of money or credit. Thus there should be no nominal magnitudes in expression (2). In any event, the model does not yet contain any money; that is added later (see expression (4) below), so expressions (1) and (2) contain only real variables. Galí's (2008: ch2) complete classical model is effectively just a simple RBC model with a money demand equation appended, as suggested by McCandless (2008).

Although an arbitrarily selected entity can act as numeraire in this model, for the reasons sketched above when discussing Wallace (2004), such an entity is not money. Although in the real world money usually acts as a numeraire, a numeraire in this model would not be money, and commodity prices expressed in terms of that numeraire should not be described as nominal magnitudes. To describe them as such distorts the English language. To reinforce the point, recall that Patinkin (1955 [1965]) and Buiter (2002; 2007) also explained that in this context the numeraire need not exist; and Wallace (2004) concurs. Obviously, as Buiter (2002) stressed, and as we noted above with respect to Wallace (2004), payment on bonds cannot be made in something that doesn't exist.

Thus it is a well-known fact that the magnitudes in expression (2) should all be defined in real commodity terms or in terms of some commodity acting as numeraire. Hence it is not the case that 'bonds', whatever they are in this context, can receive a payment of one unit of money as claimed by Galí and other theorists who employ similar specifications. In this version of the model, 'payment' can only be made in terms of some commodity.

Third, once it is acknowledged that under the time- 0 auction money has no utility, there is no sense in including money in the utility function in expression (1). This was ultimately the source of the conceptual problems in Patinkin's (1955 [1965]) attempt to integrate monetary and Walrasian general equilibrium theory. Although most contemporary monetary theorists

12. Fisher's (1907) perfect market for consumption goods loans serves the same analytical function as the time- 0 auction.

13. The fact that a time- 0 auction can never exist rather precludes the use of these models as approximations to monetary systems. 
claim, incorrectly, that money could be included in the utility function in their models (and Galí (2008: 32) follows suit), most attach a CIA constraint or a quantity equation to expressions (1)-(3). Galí (2008: 18, emphasis added) follows that route and motivates the introduction of a demand for real money balances in addition to expressions (1)-(3) along the following lines:

While the previous framework does not explicitly introduce a motive for holding money balances in some cases it will be convenient to postulate a demand for real balances with a log-linear form given by (up to an additive constant)

$$
m_{t}-p_{t}=y_{t}-\eta i_{t}
$$

where $\eta \geq 0$ is the interest semi-elasticity of money demand.

Although, like McCandless (2008), Galí warns the reader that this is ad hoc theorising, it raises more questions than he acknowledges.

To begin with, how do we know when it is convenient not to include expression (4)? But if it is inconvenient to include expression (4), then clearly the model contains no money and so no nominal magnitudes can be defined in expression (2). So how do we interpret the model without expression (4)?

To head off questions like those posed above, Galí (2008: 35) in fact makes reference to Woodford's notion of the cashless limit to justify the interpretation of the model in the money-less state - that is, when it is inconvenient to include expression (4). Galí (2008: emphasis added) explains what he is doing as follows:

The modelling approach favoured in much of the recent monetary literature, and the one adopted in this book ... does not incorporate money explicitly in the analysis. Under that approach the main role played by money is that of a unit of account. Such economies can be viewed as a limiting case (the cashless limit) of an economy in which money is valued and held by households. Woodford (2003) provides a detailed discussion and a forceful defence of that approach.

But this explanation obviously ignores the objections raised above and it should be apparent by now that those objections are not resolved by appeal to Woodford's notion of the cashless limit. The conceptual flaws in Woodford's argument are outlined in Rogers (2006; 2011) and briefly summarised as follows.

First, at its cashless limit, Woodford's (2003) model is analytically equivalent to the money-less Arrow-Debreu model and hence there is no role for money or a central bank using interest rate rules that can be used to stabilise the price level in such a model. ${ }^{14}$ That Woodford (2003) and Wallace (2004) have identical analytical structures is most obvious from Woodford's (2003: 63, emphasis added) explanation of how the price level is supposedly determined in his cashless economy:

However, assume that there exists a monetary unit of account in terms of which prices (of both goods and financial assets) are quoted. This unit of account is defined in terms of a claim to a certain quantity of the liability of the central bank which may or may not have any physical existence. ... As we shall see, the central bank's policy rule is one of the key determinants of the equilibrium price level even in a cashless economy ...

14. Woodford (2003: 64) assumes complete markets, so his model is a version of the Arrow-Debreu world of all conceivable contingent future contracts - the world of a time- 0 auction that has no role for money. Cochrane (2005) makes similar claims to Woodford for a well-specified Walrasian general equilibrium model. For a critique of Cochrane, see Rogers (2007). 
Here Woodford, like Wallace (2004), treats the numeraire as money (an obvious mistake in the context of the model) then claims simultaneously that it need not have a physical existence. Yet somehow the central bank can manipulate a quantity of this non-existent substance in terms of a policy rule that will stabilise the price level! This is just crooked thinking. Like Wallace (2004), Woodford and Galí are illegitimately conflating nominal with numeraire. ${ }^{15}$

Second, it is clear that Woodford (2003: 62) also converts money from a lubricant into a friction when he makes the assumption of frictionless financial markets and thinks it is natural to suppose that no 'monetary' assets are needed to facilitate transactions. Borio/ Disyatat (2011: 31, emphasis added) comment on Woodford as follows:

The canonical model is that of a money-less economy that can do away with the ultimate settlement medium (Woodford's (2003) 'cashless economy'). Indeed, paradoxically, when settlement balances (money) are introduced, they act as a 'friction', not as the indispensable lubricant in an otherwise ineffcient barter-exchange mechanism. It is an economy in which credit is just a vague shadow in the background [the time- 0 auction]: since credit does not affect behaviour, its evolution does not need to be tracked. ... But, even then, intermediaries do not generate purchasing power, they simply transfer real resources from one sector to the other. The underlying economy is, in this sense, a real economy disguised as a monetary one. Credit is just another real resource that households make available to entrepreneurs. This contrasts sharply with the essence of monetary analysis.

This perceptive assessment by Borio/Disyatat is a recognition of Clower's (1984) conclusion that in these models barter appears to be more efficient than monetary exchange - contra 200 years of conventional wisdom. Consequently, Woodford's analysis of the cashless limit does not provide the theoretical foundations for monetary policy as claimed by the subtitle to his book or by Galí (2008). Woodford fails for the same reason that Patinkin (1955 [1965]) failed to integrate monetary and value theory in his WAD general equilibrium model; money into WAD general equilibrium theory won't go.

Furthermore, from Hahn's (1965) perspective, Woodford and Galí operate by sleight of mind when they eliminate an inessential entity called money and describe the resultant state of the model as the 'cashless limit' - the cashless limit is simply the core WAD general equilibrium solution with the inessential CIA constraint or money demand equation removed. The inessential addition of a money demand equation or CIA constraint always leaves the WAD real equilibrium intact - so its removal is always benign.

To sum up, the fundamental flaw in NK monetary theory based on the microeconomic foundations embedded in expressions (1)-(3), correctly interpreted, is that the choice problem specified by expression (1) is only well specified under a time-0 auction. That auction can be interpreted as an analytical substitute for money, so attempts to find an additional role for money as specified by expression (4) introduce a conceptual error by inserting money into a model where it is not required.

\subsection{Central banks and dynamic stochastic general equilibrium (DSGE) NK models}

In his review of Woodford (2003), Green (2005) explicitly recommends Woodford's analysis on the grounds that central bankers will have a well-specified model with which to work. Similar endorsement appears on Galî’s (2008) book. The Smets/Wouters (2003; 2007) models take this advice to heart. But, as outlined above, that advice is misguided, as

15. This muddle explains why Buiter (2007) asks if numerairology is the future of monetary economics. 
DSGE models with RBC or Walrasian microfoundations inherit the conceptual confusions about money embedded in the microeconomic foundations they employ.

This is most obvious in Smets/Wouters (2003) where their DSGE model of the euro area follows the Woodford-(2003)-Galí-(2008) strategy of appending 'nominal' frictions and rigidities to an otherwise RBC core. Smets/Wouters (2003: 1126) describe their model as follows:

The model is an application of the real business cycle (RBC) methodology to an economy with sticky prices and wages.

In short, Smets/Wouters (2003) use a more complex version of Woodford (2003) or Galí (2008). So, even if calibration and estimation of parameters somehow neutralise the conceptual flaws in the theoretical core of their model (by a process of compensating errors?), it is difficult to know how to interpret their results. Why should we then be surprised that DSGE models were no help in anticipating the GFC and the subsequent euro crises? ${ }^{16}$

\section{THE SCIENTIFIC ILLUSION OF CONTEMPORARY MONETARY THEORY; WHY SO FEW CAN SEE THAT THE EMPEROR HAS NO CLOTHES}

The above discussion raises an obvious question. If McCandless, Wallace and Galí, for example, are aware that they are using such ad hoc models that also exhibit conceptual inconsistencies, why do they continue to use them? ${ }^{17}$ As Solow (2010: 3) put the question: how was it that the macroeconomics/monetary profession was led down this particular garden path?

Krugman (2009) put it down to a preference for beauty over substance. By 'beauty', Krugman meant mathematical elegance and sophistication, and that seems to be at least part of the explanation. Krugman's view is consistent with the sentiments expressed by Wallace, who sees the WAD core as the 'developed' part of economic theory while monetary theory is seen to be 'undeveloped'. Even Hahn, who was critical of the illadvised applications of the WAD core to monetary theory, nevertheless believed that the WAD core was the framework within which to proceed. His was an internal critique (Kirman 1989).

Associated with views about the desirability of mathematical elegance and sophistication is the notion that such work is 'scientific' because it mimics the methods of the hard sciences like physics. This view is apparent in Clarida et al. (1999) who, without explanation, interpret the consensus on monetary policy achieved during the 1990s as implying 'scientific' status for monetary theory. A similar view is apparent in Wieland (2010). It seems that contemporary monetary economists are equating consensus with science; but the scientific method does not require consensus, it requires the rooting out of bad theory. That has clearly not been done, perhaps because the supposedly scientific status of the approach also appeals to those who have already decided that the WAD core provides the appropriate microeconomic foundations for aggregate monetary and

16. For a perceptive assessment of DSGE models based on an RBC core, see Macroeconomic Advisors (2010). It is clear that from the perspective of RBC theory, the GFC needs to be interpreted as a technology 'shock'. For example, the Lehman collapse could be treated as a shock to the 'storage technology' of Allen/Gale (2007). See also Solow (2010) for a critique of DSGE models. 17. To be fair, Wallace (2001) is clearly looking for a way out of the cul-de-sac posed by the WAD general equilibrium core. 
macroeconomic theory - despite the warnings by Hahn (1982), Solow (1986; 2010) and Kirman (1989). ${ }^{18}$

But that cannot be the whole story, because despite their mathematical elegance and sophistication, these models exhibit some rather gross conceptual errors. It seems that today too many monetary theorists are uncritically writing down equations that do not make any economic sense. Consideration of why they do that would take us well beyond the bounds of this paper and into the realm of the 'sociology of knowledge'. Suffice it to say that once a flawed paradigm with a preference for mathematical elegance has become established, numerous self-reinforcing mechanisms also come into existence - self-selection of individuals with the necessary mathematical skills; cliques or clubs that control prestigious journals; economics departments that teach only the accepted paradigm; prestigious awards to some exponents of the club that reinforce belief in the paradigm; the peer pressure to be wrong within the paradigm rather than unconventionally correct; and so on. Consequently many economists, for example Wieland (2010), think that the state of contemporary monetary/macroeconomic theory is just fine.

These tendencies will always exist in any discipline to a greater or lesser extent, and science progresses by weeding out the degenerate paradigms. Unfortunately, in economics that process seems to take longer (recall the swift despatch of the notion of cold fusion), but the time for such a shift in monetary paradigm is now ripe, as many have recognised.

\section{CONCLUDING REMARKS}

The uselessness of 'state of the art' monetary theory highlighted by Buiter (2009) can be traced to the obsession that monetary theorists have for WAD general equilibrium theory. Although the WAD general equilibrium core may have its uses, monetary theory is not one of them.

A time- 0 auction is necessary to construct any WAD general equilibrium system, but, as Hahn and others warned, that precludes any sensible role for money and banking. Proceeding despite warnings about this limitation on the grounds that the WAD core is 'scientific' or provides the microeconomic foundations for monetary theory is simply unscientific by any standard. The GFC of 2007-2008 is a timely reminder that this approach to monetary theory should be abandoned. Exponents of NC, RBC or NK 'state of the art' monetary models inhabited a world where the events of 2007-2008 simply could not happen.

Is it any wonder that academics, regulators and central bankers armed with 'calibrated' DSGE versions of these models failed to see the global financial crisis coming?

18. Kirman (1989) explains why the Emperor has no clothes when it comes to applications of the WAD core to aggregate or macroeconomic analysis without even considering the conceptual confusion posed by its attempts to incorporate money. 


\section{REFERENCES}

Allen, F., Gale, D. (2007): Understanding Financial Crises, Oxford: Oxford University Press.

Benassy, J.-P. (2007): Money, Interest, and Policy: Dynamic General Equilibrium in a Non-Ricardian World, Cambridge MA: MIT Press.

Borio, C., Disyatat, P. (2011): Global imbalances and the financial crisis: link or no link? Bank of International Settlements, Working Paper, No. 346.

Buiter, W.H. (1998): The young person's guide to neutrality, price level indeterminacy, interest rate pegs, and fiscal theories of the price level, National Bureau of Economic Research, Working Paper, No. 6396.

Buiter, W.H. (2002): The fallacy of the fiscal theory of the price level: a critique, in: Economic Journal, 112, 459-480.

Buiter, W.H. (2004): New developments in monetary economics: two ghosts, two eccentricities, a fallacy, a mirage and a mythos, Royal Economic Society, Annual Conference, Swansea.

Buiter, W.H. (2007): Is numerairology the future of monetary economics? Unbundling numeraire and medium of exchange through a virtual currency and a shadow exchange rate, National Bureau of Economic Research, Working Paper, No. 12839.

Buiter, W. (2008): Central banks and financial crises, Paper presented at the Federal Reserve Bank of Kansas City's symposium on Maintaining Stability of the Changing Financial System, at Jackson Hole, Wyoming, 21-23 August.

Buiter, W. (2009): The unfortunate uselessness of most 'state of the art' academic monetary economics, URL: VoxEU.org.

Clarida, R., Galí, J., Gertler, M. (1999): The science of monetary policy: a New Keynesian perspective, in: Journal of Economic Literature, 37(4), 1661-1707.

Clower, R.W. (1984): Money and markets, in: Walker, Donald A. (ed.), Money and Markets: Essays by Robert W. Clower, Cambridge, UK: Cambridge University Press.

Clower, R.W. (1999): Post-Keynes monetary and financial theory, in: Journal of Post Keynesian Economics, 21(3), 399-414.

Cochrane, J.H. (2005): Money as stock, in: Journal of Monetary Economics, 52(3), 501-528.

Debreu, G. (1959): The Theory of Value: An Axiomatic Analysis of Economic Equilibrium, New Haven, CT and London: Yale University Press.

Dullien, S. (2009): The new consensus from a traditional Keynesian and post-Keynesian perspective: a worthwhile foundation for research or just a waste of time? IMK Working Paper, No. 12/2009, Düsseldorf.

Fisher, I. (1907): The Rate of Interest: Its Nature, Determination and Relation to Economic Phenomena, New York: Macmillan.

Frankel, J. (2009): Why did economists get it so wrong? Krugman is right, URL: http://www. economonitor.com/.

Galí, J. (2008): Monetary Policy, Inflation and the Business Cycle: An Introduction to the New Keynesian Framework, Princeton, NJ: Princeton University Press.

Goodhart, C.A.E. (2005): The foundations of macroeconomics: theoretical rigour versus empirical realism? London School of Economics, Financial Markets Group, IRES Conference on The History of Macroeconomics, Louvain-la-Neuve, 20-22 January 2005.

Goodhart, C.A.E. (2009): The continuing muddles of monetary theory: a steadfast refusal to face the facts, in: Economica, 76, 821-830.

Green, E.J. (2005): A review of interest and prices: foundations of a theory of monetary policy, in: Journal of Economic Literature, 43(1), 121-134.

Hahn, F.H. (1965): On some problems of proving the existence of equilibrium in a monetary economy, in: Hahn, F.H., Brechling, F.P.R. (eds), The Theory of Interest Rates, London: Macmillan, 126-135.

Hahn, F.H. (1973a): On the foundations of monetary theory, in: Parkin, Michael (ed.), Essays in Modern Economics, London: Longman, 230-242.

Hahn, F.H. (1973b): On transactions costs, inessential sequence economies and money, in: Review of Economic Studies, 40(4), 449-461.

Hahn, F.H. (1982): Money and Inflation, Oxford: Basil Blackwell.

Hoover, K. (1988): New Classical Macroeconomics: A Sceptical Inquiry, Oxford: Blackwell. 
Kirman, A. (1989): The intrinsic limits on modern economic theory: the Emperor has no clothes, in: Economic Journal (Conference Volume), 126-139.

Krugman, P. (2009): How did economists get it so wrong? in: New York Times, 9 September, URL: nytimes.com.

Laidler, D. (1990): Taking Money Seriously, New York: Philip Allan.

Ljungqvist, L., Sargent T.J. (2004): Recursive Macroeconomic Theory, 2nd edn, Cambridge, MA: MIT Press.

Lucas, R. (2009): In defence of the dismal science, in: The Economist, 8 August, URL: economist.com.

Macroeconomic Advisors (2010): The Emperor has no clothes, in: Macro Focus, 24 June, 5(2), 1-14.

McCallum, B.T. (1985): Bank deregulation, accounting systems of exchange, and the unit of account: a critical review, in: Brunner, Karl, Meltzer, Allan (eds), The 'New Monetary Economics', Fiscal Issues and Unemployment, Carnegie-Rochester Conference Series on Public Policy, vol. 23, Amsterdam: North Holland, 13-46.

McCallum, B.T. (2004): Monetary policy in economies with little or no money, in: Pacific Economic Review, 9(2), 81-92.

McCandless, G. (2008): The ABCs of RBCs: An Introduction to Dynamic Macroeconomic Models, Cambridge, MA: Harvard University Press.

Patinkin, D. (1955 [1965]): Money Interest and Prices: An Integration of Monetary and Value Theory, 2nd edn (1965), New York: Harper and Row. (2nd edn abridged (1989), Cambridge, MA: MIT Press.)

Purvis, D.D. (1971): Introducing useful money into a growth model, in: The Canadian Journal of Economics, 4(3), 374-381.

Reis, R. (2007): The analytics of monetary non-neutrality in the Sidaurski model, in: Economics Letters, 94(1), 129-135.

Rodrik, D. (2009): The sorry state of (macro) economics, URL: http://rodrik.typepad.com.

Rogers, C. (2006): Doing without money: a critical assessment of Woodford's analysis, in: Cambridge Journal of Economics, 30(2), 293-306.

Rogers, C. (2007): Do frictionless models of money and the price level make sense? University of Adelaide, School of Economics, unpublished Working Paper.

Rogers, C. (2011): The failure of Woodford's model of the channel system at the cashless limit, in: Journal of Money Credit and Banking, 43(2-3), 535-563.

Rogers, C. (2013): The scientific illusion of New Keynesian monetary theory, in: Harcourt, Geoffrey, Kriesler, Peter (eds), The Handbook of Post Keynesian Economics, Oxford: Oxford University Press, 167-187.

Sidrauski, M. (1967): Rational choices and patterns of growth in a monetary economy, in: American Economic Review, 57, 534-544.

Smets, F., Wouters, W. (2003): An estimated dynamic stochastic general equilibrium model of the euro area, in: Journal of the European Economic Association, 5, 1123-1175.

Smets, F., Wouters, W. (2007): Shocks and frictions in US business cycles: a Bayesian DSGE approach, in: American Economic Review, 97(3), 586-606.

Solow, R. (1986): What is a nice girl like you doing in a place like this? Macroeconomics after 50 years, in: Eastern Economic Journal, 12(3), 191-198.

Solow, R. (2010): Building a science of economics for the real world, House Committee on Science and Technology Subcommittee on Investigations and Oversight, 20 July.

Wallace, N. (2001): Whither monetary economics? Lawrence R. Klein Lecture 2000, in: International Economic Review, 42(4), 847-869.

Wallace, N. (2004): Central-bank interest-rate control in a cashless, Arrow-Debreu economy, Unpublished working paper, Department of Economics, Pennsylvania State University.

White, W.R. (2009): Modern macroeconomics is on the wrong track, in: Finance and Development, December, 15-18.

Wieland, V. (ed.) (2010): The Science and Practice of Monetary Policy Today, Heidelberg: Springer.

Williamson, S., Wright, R. (2010): New monetarist economics: methods, in: Federal Reserve Bank of St Louis Review, July/August, 265-302.

Woodford, M. (2003): Interest and Prices: Foundations of a Theory of Monetary Policy, Princeton, NJ: Princeton University Press. 